\title{
Hydatid Cyst of the Breast Diagnosed by Fine Needle Aspiration Cytology
}

\section{Tanısı İnce İğne Aspirasyon Sitolojisi İle Konulan Meme Hidatid Kisti}

\author{
Serpil KAPLAN, Gülçin YEĞEN, Serap KOÇ \\ Department of Pathology, M. H. State Hospital, VAN, TURKEY
}

\begin{abstract}
Hydatid disease of the breast is rare. It can be isolated in the breast or associated with other localizations. A hydatid breast cyst is diagnosed by observing hooklets and scolices obtained by fine needle aspiration cytology. Hydatid disease must be considered in the differential diagnosis of breast disease in endemic regions.

We report a case presenting with a hydatid cyst of the breast as the breast is a rare location for hydatid cyst, and it was diagnosed by fine needle aspiration cytology.
\end{abstract}

Key Words: Breast, Fine needle aspiration, Cytology, Hydatid cyst

\section{ÖZ}

Memenin hidatid kisti son derece nadirdir. Memede izole olabileceği gibi diğer lokalizasyonlarla ilişkili de olabilir. Hidatid meme kistine uygulanan ince iğne aspirasyon sitolojisinde kancalar ve skolekslerin görülmesiyle tanı konulur. Endemik bölgelerde meme hastalıkları için ayırıcı tanıda yer almalıdır.

Biz meme kist hidatidli bir hastayı nadir bir yerleşim yeri olması ve ince iğne aspirasyon sitolojisi ile tanısının konulması nedeniyle sunduk.

Anahtar Sözcükler: Meme, İnce iğne aspirasyonu, Sitoloji, Hidatid kist

\section{INTRODUCTION}

Hydatid cyst is a parasitic disease caused by Echinococcus granulosus larvae (1-4). The larval cysts are most commonly found in the lung $(25 \%)$ and liver $(70 \%)$ but cysts may involve any part of the body (1-5). The breast is a rare location for hydatid cyst even in endemic areas and makes up only $0.27 \%$ of all cases (1-11). Development in the breast can be primary or secondary to disseminated hydatidosis (systemic spread) $(5,10)$. There are only a few cases of breast hydatid cyst diagnosed by needle aspiration biopsy in the literature $(4,6,8)$.

\section{CASE REPORT}

A 32-year-old woman who had been operated for a pulmonary hydatid cyst 8 years before presented at the General Surgery Outpatients Department with a painful mass of the left breast. Laboratory results were normal. The USG revealed a trilobulated $32 \times 15 \mathrm{~mm}$ cystic mass at the 12 oclock position. The findings were first thought to be indicative of a recurrence as the patient had a history of hydatid cyst and she underwent fine needle aspiration

Received : 17.05.2009

Accepted : 24.08.2009 biopsy. No complications developed during the aspiration. Smears were stained with the Papanicolaou stain. Cytological examination revealed scolices and calcification together with hook structures spread in the background (Figure 1,2), which led to a report of hydatid cyst. The lesion was excised totally.

\section{DISCUSSION}

Hydatid disease of the breast is rare and breast can be the primary localization but it can also appear secondary to systemic spread (1-10). Hydatid cyst creates an important problem regarding the differential diagnosis especially when cysts with an atypical location develop. Mammography and USG are inadequate in diagnosing hydatid cyst of the breast. Imaging features of hydatid cyst are nonspecific and may be confused with fibroadenoma, philloides tumor and carcinomas (1,8-11). Serological tests are also not always positive for hydatid disease $(1,2,5,11)$. Fine needle aspiration cytology is valuable in definite diagnosis but the risk of contamination and anaphylaxis must be kept in mind in cases with hydatid cyst $(4,5)$. However, neither our

Correspondence: Serpil KAPLAN

Department of Pathology, M. H. State Hospital, VAN, TURKEY

E-mail: drskaplan28@yahoo.com Phone: +90 4322157607 


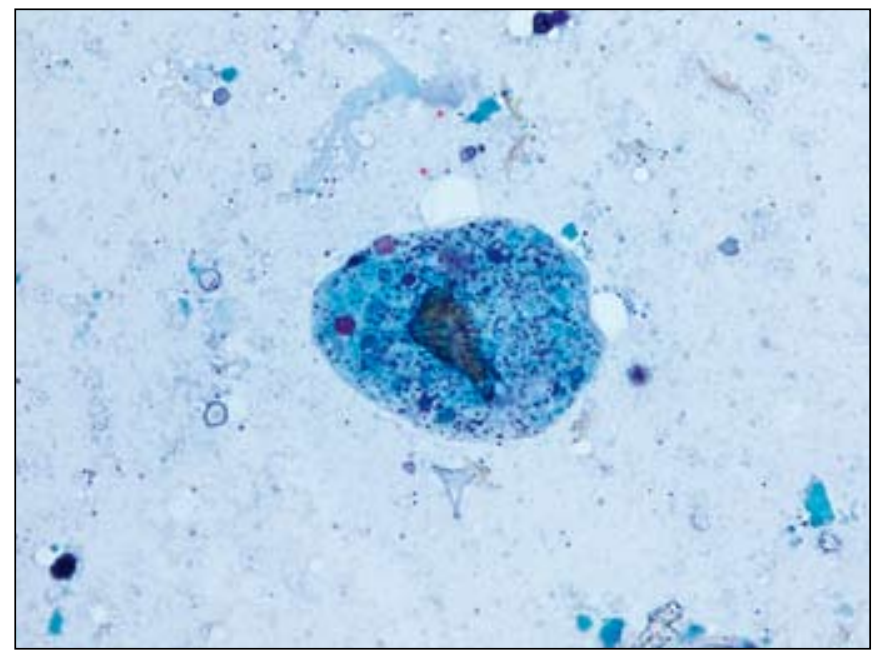

Figure 1: Scolex structure containing hooks (Pap stain, x400).

case, nor any case in the literature suffered from anaphylaxis $(1,3,6,8,10,11)$. The diagnosis of hydatid disease is made by the observation of scolices, hooks or pieces of lamellar membrane $(1,2,12)$. Scolices are long, oval structures. Hooks contains black central cores. The lamellar membrane contains parallel laminations $(1,3,6,7)$.

In conclusion, hydatid cyst is rare in the breast but should be considered in the differential diagnosis when examining cytological preparations from breast lesions especially in endemic areas.

\section{REFERENCES}

1. Acar T, Gömcel Y, Güzel K, Yazgan A, Aydin R: Isolated hydatid cyst of the breast. Scott Med J 2003, 48: 52-53

2. Yildirim M, Erkan N, Vardar E: Hydatid cysts with unusual localizations: diagnostic and treatment dilemmas for surgeons. Ann Trop Med Parasitol 2006, 2: 137-142

3. Să̆in HB, Kiroğlu Y, Aksoy F: Hydatid cyst of the breast diagnosed by fine needle aspiration: a case report. Acta Cytol 1994, 38: 965-967

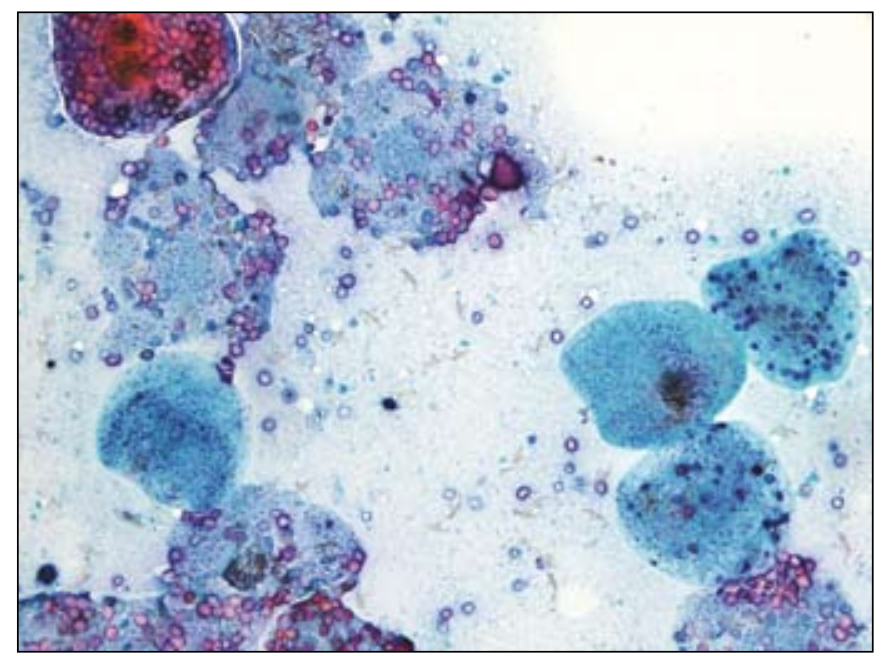

Figure 2: Hook structures, calcification and scolices (Pap stain, $\mathrm{x} 200)$.

4. Arikan S, Yucel AF, Barut G, Kocakusak A. Hydatid disease in the breast: a case report. Acta Chir Belg 2004, 104: 473- 475

5. Erkan N, Haciyanli M, Yildırim M, Yilmaz C: A case report of the unusual presence of hydatid disease in the pancreas and breast. JOP. 2004, 5: 368-372

6. Geramizadeh B, Boob R, Talei AR, Rasekhi A: Fine needle aspiration cytology in hydatid cyst of the breast. Acta Cytol 2003, 47: 701-702

7. Dogan BE, Tukel S, Ceyhan K: Hydatid cyst of the breast. Curr Probl Diagn Radiol 2005, 34: 204- 205

8. Vega A, Ortega E, Cavada A, Garijo F: Hydatid cyst of the breast: mammographic findings. Am J Roentgenol 1994, 162: 825- 826

9. Yuksel BC, Ozel H, Akin T, Avsar F, Hengirmen S: Primary hydatid cyst of the breast with elevated CA 19-9 level. Am J Trop Med Hyg 2005, 73: 368- 370

10. Yaghan RJ: Hydatid disease of the breast: a case report and literature review. Am J Trop Med Hyg 1999, 61: 714- 715

11. Jarbou S, Salaita W, Khasawneh M: Isolated hydatid cyst of breast: a case report. JRMS 2007, 14: 64- 65

12. Grace C H Yang and Liang-Che Tao: Liver and Pancreas. In Marluce Bibbo, David C Wilbur (eds). Comprehensive Cytopathology. 3rd ed., Philadelphia, Elsevier, 2008, 876 